Bull. Chem. Soc. Ethiop. 2021, 35(3), 551-564.

(c) 2021 Chemical Society of Ethiopia and The Authors

ISSN 1011-3924

DOI: https://dx.doi.org/10.4314/bcse.v35i3.7

Printed in Ethiopia

Online ISSN 1726-801X

\title{
SYNTHESIS AND BIOLOGICAL EVALUATION OF SOME HYBRID 2-QUINOLINONE DERIVATIVES CONTAINING CINNAMIC ACID AS ANTI-BREAST CANCER DRUGS
}

\author{
Safyah B. Bakare* \\ Faculty of Education, Shaqra University, Al Muzahimiyah, Shaqra, Riyadh Province, \\ P.O. Box 205, Zip Code 11972, Saudi Arabia
}

(Received February 11, 2021; Revised December 20, 2021; Accepted December 20, 2021)

\begin{abstract}
A new series of hybrid 2-quinolinone derivatives were synthesized by using 7-hydroxy-4-methyl1-amino-quinolin-2-one (2) and cinnamic acid. Hybrid halogenated 2-quinolinone derivatives (3-(7-hydroxy-4methyl-3,6,8-tribromo-2-oxo-2H-quinolin-1-ylamino)-3-phenyl acrylic acid (4) and 3-(7-acetoxy-4-methyl-3,6,8tribromo-2-oxo-1H-quinolin-1-ylamino)-3-phenyl acrylic acid (7)) were prepared via the halogenation of 3-(7hydroxy-4-methyl-2-oxo-2H-quinolin-1-ylamino)-3-phenyl acrylic acid (3) with bromine to give compound 4 with acetic anhydride led to the formation of hydride halogenated 2-quinolinone derivative (7). All the synthesized hybrid 2-quinolinone and hybrid halogenated 2-quinolinone derivatives were tested for their cytotoxicity against MCF-7 cell line. DNA flow cytometric analysis of compounds 3 showed cell cycle arrest at $\mathrm{G}_{2} / \mathrm{M}$ phase with concomitant increase of cells in apoptotic phase. Dual annexin-V/propidium iodide staining assay of compound $\mathbf{3}$ revealed that, the selected molecule increases the apoptosis of MCF-7 cells more than control.
\end{abstract}

KEY WORDS: Quinolinone, Hybrid, Cinnamic acid, Apoptosis, MCF-7 cells

\section{INTRODUCTION}

Several authors have reported that numerous quinolinone derivatives showed strong antiproliferative activity and induce apoptosis in various cancer cell lines [1,2]. Cliquinol is an antibiotic with metal-binding properties which has been shown to have anticancer activity in several experimental model system [3-6]. All these studies strongly support the potential therapeutic application of quinolinone derivatives, making them attractive for their further evaluation as novel therapeutic agents for cancer treatment. Some studies found that numerous quinolinone derivatives display potent anticancer activity by targeting different cellular pathways, including multidrug resistance, proliferation, and apoptosis [7-9]. Apoptosis is a programmed cell death, an important control mechanism of normal cell physiology [10, 11]. Deficiency in apoptosis is one of the key features of cancer cells [12].

Kemnitzer et al. [13] found a new series of apoptosis inducers, the 1-benzoyl-3cyanopyrrolo[1,2-a]quinolines (Formula I), among which the compound 1-(4-(1H-imidazol-1yl)benzoyl)-3-cyanopyrrolo[1,2-a]quinolone (Formula II) displayed high cytotoxic activity in T47D human breast cancer, HCT-116 human colon cancer cells and SNU398 hepatocellular carcinoma cells. 2-quinolone derivatives have been shown to have antitumor, antimalarial, antiviral, antioxidant, antidepressant, cardiac stimulant, and anti-asthmatic biological activity [1424]. Quinoline is a scaffold with pharmacological value spread in a variety of synthetic and natural compounds that are bioactive [25]. Throughout the twentieth century, quinoline chemistry has been the subject of extensive study and various interesting biological activities such as antibacterial, antifungal, inflammatory, anti-malarial and anti-cancer activities [26]. This anticancer activity is very broad, as quinoline derivatives have been used against many types of cancer, such as breast, prostate, gastrointestinal, colon and liver cancer [27]. Importantly, a few anticancer drugs containing quinoline have also been used clinically, including camptothecin and

*Corresponding author. E-mail: safyahbakare@gmail.com

This work is licensed under the Creative Commons Attribution 4.0 International License 
its analogs (irinotecan and topotecan) [28, 29] and bosutinib. To discover new bioactive compounds for medicinal purposes, in the present study, an attempt was made to prepare other new structures nearing existing quinolone ones present in the marketed drugs, containing cinnamic acid as natural product isolated from plants to achieve improved biological activities of the parent compounds. Herein, we report the synthesis of a series from quinlinone derivatives containing cinnamic acid as natural product from the reaction of 7-hydroxy-4-methyl-2-oxo- $2 \mathrm{H}$ quinolin-amine with cinnamic acid to study their structure activity relationship and to screen as anti-breast cancer drugs. The structure of synthesized 2-quinolinone derivatives is shown in (Formula III).

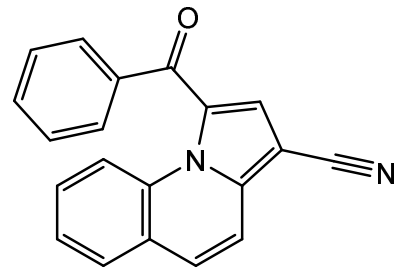

Formula I

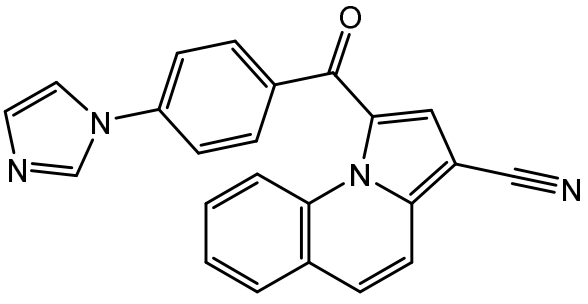

Formula II

Table 1. Structures of the synthesized 2-quinolinone derivatives.

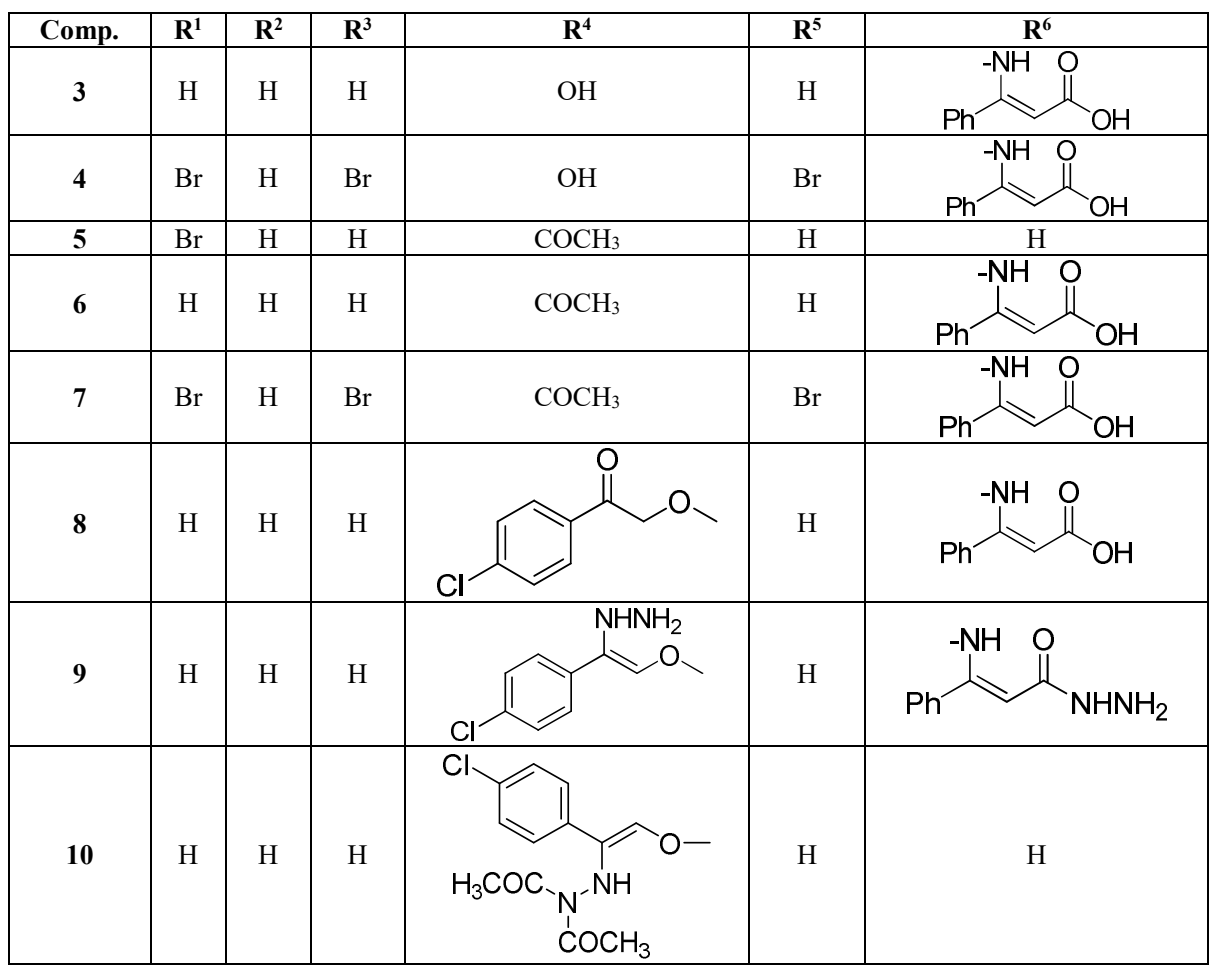




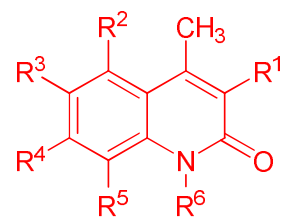

(Formula III)

\section{EXPERIMENTAL}

${ }^{1} \mathrm{H}-\mathrm{NMR}$ spectra were recorded using Bruker 400 DRX-Avance NMR spectrometer. Chemical shifts of ${ }^{1} \mathrm{H}-\mathrm{NMR}$ spectra were reported relative to tetramethylsilane (TMS). ${ }^{13} \mathrm{C}-\mathrm{NMR}$ spectra were run using a Bruker DRX-Avance NMR spectrometer. The prepared compounds were dissolved in deuterated dimethyl sulfoxide (DMSO) as solvent. Splitting patterns were reported as s, singlet; d, doublet; t, triplet; q, quartet; m, multiplet; br, broad. IR spectra were recorded using a broker FT-8000 spectrometer and frequencies were expressed in $\mathrm{cm}^{-1}$. The molecular weight of the prepared compounds was determined by electron ionization (EI) mass spectrometer operating at $70 \mathrm{eV}$. Melting point of the synthesized compounds was measured with an electrothermal melting point apparatus and has not been corrected. All the prepared compounds give satisfactory elemental analyses within $0.04 \%$ of the theoretical values. The elemental analyses were carried out on a Perkin-Elmer 2400 series CHN. Chemicals and solvents were purchased from commercial sources in analytical grade purity.

Synthesis of 3-(7-hydroxy-4-methyl-2-oxo-2H-quinolin-1-ylamino)-3-phenyl acrylic acid (3)

The synthesis of 7-hydroxy-4-methylcoumarin (1) and 7-hydroxy-4-methyl-1-amino-2quinolinone (2) were carried out according to literature procedure [30-32].

A mixture of 1-aminoquinolinone derivative $2(0.01 \mathrm{~mol})$, cinnamic acid $(0.01 \mathrm{~mol})$ and fused sodium acetate $(0.03 \mathrm{~mol})$ in ethanol $(50 \mathrm{~mL})$ was heated under reflux for $6 \mathrm{~h}$. The reaction mixture was cooled and poured into water with stirring; the solid formed was filtered off, washed with water, and dried. Finally, the product was crystallized from to give compound $\mathbf{3}$.

As pale-yellow crystals, yield $69 \%$, m.p. $121-123{ }^{\circ} \mathrm{C}$. IR (KBr) $v_{\max }: 3285(\mathrm{NH}), 3380-3050$ (br. OH), 1711-1705 (C=O), 1605, $1583(\mathrm{C}=\mathrm{C}), 1215,1171,1083(\mathrm{C}-\mathrm{O}) \mathrm{cm}^{-1} .{ }^{1} \mathrm{H}-\mathrm{NMR}$ (DMSO$\left.d_{6}\right) \delta: 2.36\left(\mathrm{~s}, 3 \mathrm{H}, \mathrm{CH}_{3}\right), 6.13(\mathrm{~s}, 1 \mathrm{H}, \mathrm{H}-3$ of quinolinone ring), 6.51-7.71 (m, $10 \mathrm{~h}, \mathrm{Ar}-\mathrm{H}, \mathrm{H}-$ olefinic and $\mathrm{NH}), 10.55(\mathrm{~s}, 1 \mathrm{H}, \mathrm{OH}) \mathrm{ppm} .{ }^{13} \mathrm{C} \mathrm{NMR}\left(\mathrm{DMSO}-d_{6}\right) \delta: 168.05(\mathrm{C}=\mathrm{O}), 161.61,160.79$, $155.29,154.08,127.13,113.33,112.49,110.71,102.63$ (C2, C7, C3, C6, C8, C5, C4, C9, C10 of quinolinone ring), 144.43, 134.66, 130.71, 129.38, 128.68, 119.64 (C-aromatic and olefinic), $18.59\left(\mathrm{CH}_{3}\right)$ ppm. MS: $\mathrm{m} / \mathrm{z}(\%)=336\left(\mathrm{M}^{+}, 17.50\right)$. Anal. calcd. for $\mathrm{C}_{19} \mathrm{H}_{16} \mathrm{~N}_{2} \mathrm{O}_{4}$ (336): $\mathrm{C}, 67.86$; H, 4.76; N, 8.33. Found: C, 67.57; H, 4.41; N, 8.11.

Synthesis of 3-(7-hydroxy-4-methyl-3,6,8-tribromo-2-oxo-2H-quinolin-1-ylamino)-3-phenyl acrylic acid (4)

In $30 \mathrm{~mL}$ of glacial acetic acid, compound $3(0.01 \mathrm{~mol})$ was dissolved, then $15 \mathrm{~mL}$ of bromine $(0.03 \mathrm{~mol})$ in glacial acetic acid was added dropwise to compound 3 solutions with stirring at 60 ${ }^{\circ} \mathrm{C}$. After 5-10 min the bromine color was discharged, and yellow solution remained. At this point, $0.5-1 \mathrm{~mL}$ of the bromine-AcOH solution was added with stirring at room temperature for 30-45 min. The reaction mixture was poured into water, and the resulting solid was filtered off, washed with water, and dried. Finally, the product was crystallized from ethanol to give 4. 
As pale-yellow crystals, yield $81 \%$, m.p. $149-151{ }^{\circ} \mathrm{C}$. IR (KBr) $v_{\max }: 3405-3015$ (br. OH), $3287(\mathrm{NH}), 1725-1705(\mathrm{C}=\mathrm{O}), 1612,1592(\mathrm{C}=\mathrm{C}), 1212,1179,1069(\mathrm{C}-\mathrm{O}) \mathrm{cm}^{-1} .{ }^{1} \mathrm{H}-\mathrm{NMR}$ $\left(\right.$ DMSO- $\left.d_{6}\right) \delta: 2.55\left(\mathrm{~s}, 3 \mathrm{H}, \mathrm{CH}_{3}\right), 5.32$ (d, 1H, H-olefinic), 5.54 (d, 1H, H-olefinic), 6.89-8.07 (m, $7 \mathrm{H}$, ar-H and $\mathrm{NH}), 11.49(\mathrm{~s}, 1 \mathrm{H}, \mathrm{OH}) 11.57(\mathrm{~s}, 1 \mathrm{H}, \mathrm{OH}), 13.83$ (br. s, $1 \mathrm{H}, \mathrm{OH}) \mathrm{ppm} .{ }^{13} \mathrm{C} \mathrm{NMR}$ $\left(\mathrm{DMSO}-d_{6}\right) \delta: 193.36(\mathrm{C}=\mathrm{O}$ of ketone), 168.06, 167.15 ( $\mathrm{C}=\mathrm{O}$ of acid), 161.61, 161.46, 160.78, $160.59,155.29,155.09,154.05,153.87,127.58,127.11,113.91,113.38,113.04,112.48,111.47$, $110.71,102.63,102.06$, (carbons of two isomers quinolinone ring), 145.03, 144.42, 139.25, $134.67,134.44,133.35,130.98,129.25,128.67,127.89,126.91,119.64,118.25$ (C-aromatic and olefinic), $71.01\left(\mathrm{CH}_{2}-\mathrm{O}\right), 51.96$ (CH-olefinic), 18.61, $18.58\left(2 \mathrm{x} \mathrm{CH}_{3}\right) \mathrm{ppm} . \mathrm{MS}: \mathrm{m} / \mathrm{z}(\%)=448$ $\left(\mathrm{M}^{+}, 6.70\right)$. Anal. calcd. for $\mathrm{C}_{27} \mathrm{H}_{21} \mathrm{ClN}_{2} \mathrm{O}_{5}$ (488): C, 66.39; H, 4.30; N, 5.74. Found: $\mathrm{C}, 66.16 ; \mathrm{H}$, $4.18 ; \mathrm{N}, 5.55$.

Synthesis of 3-(7-( $\beta$-hydrazino, $\quad \beta$-p-chlorophenyl-vinyloxy-4-methyl-2-oxo-1H-quinolin-1ylamino]-3-phenylacrylic acid hydrazide (9)

A mixture of equimolar of compound $9(0.01 \mathrm{~mol})$ and hydrazine hydrate $(0.01 \mathrm{~mol})$ in $30 \mathrm{~mL}$ absolute ethanol was heated under reflux for 3-4 h. the solution was cooled, and the resulting solid was filtered off, washed with water and dried. Finally, the product was crystallized from ethanol to give 9.

As yellow crystals, yield $67 \%$, m.p. $168-170{ }^{\circ} \mathrm{C}$. IR $(\mathrm{KBr}) v_{\max }: 3415,3280,3158\left(\mathrm{NH}_{2} \mathrm{NH}\right)$, 1705-1689 (C=O), 1612, $1587(\mathrm{C}=\mathrm{C}), 1215,1163,1082(\mathrm{C}-\mathrm{C}) \mathrm{cm}^{-1} .{ }^{1} \mathrm{H}-\mathrm{NMR}$ (DMSO- $\left.d_{6}\right) \delta: 1.06$ (d, 2h, nh2), 2.36 (s, 3h, ch3), 2.38 (s, 3h, ch3), 4.93 (s, 1h, h-olefinic), 5.16 (s, 1h, h-olefinic), 6.13-7.68 (m, 18H, h-quinolin, Ar-H, H-olefinic and NH) ppm. ${ }^{13} \mathrm{C}-\mathrm{NMR}$ (DMSO- $d_{6}$ ) $\delta: 161.76$ $(\mathrm{C}=\mathrm{O}), 161.62$, 161.42, 160.78, 160.60, 155.29, 155.07, 154.06, 153.91, 127.12, 127.07, 113.86, $113.67,113.15,112.48,111.66,110.71,108.63,102.12$ (C-aromatic of two isomer of quinolinone ring), 139.00, 137.35, 137.03, 133.48, 131.93, 131.72, 130.32, 129.48, 129.05, 128.84, 128.60, $126.89,101.80$ (carbons of two isomer $\mathrm{O}-\mathrm{CH}_{2}$ ), 19.03, 18.59 (carbons of two isomer of methyl). MS: $\mathrm{m} / \mathrm{z}(\%)=516\left(\mathrm{M}^{+}, 17.31\right)$. Anal. calcd. for $\mathrm{C}_{27} \mathrm{H}_{21} \mathrm{ClN}_{6} \mathrm{O}_{3}(516): \mathrm{C}, 62.79 ; \mathrm{H}, 4.84 ; \mathrm{N}, 16.28$. Found: C, 62.52; H, 4.59; N, 16.06.

General procedure for the acetylation reaction

A solution of compounds 3,4 and $9(0.01 \mathrm{~mol})$ in acetic anhydride $(30 \mathrm{~mL})$ was heated under reflux $2 \mathrm{~h}$, then cooled and poured into ice-water with stirring. The reaction mixture was left 24 $\mathrm{h}$; the solid formed was filtered off, washed with water and dried. Finally, the solid product was crystallized from ethanol to give 6, 7 and 10, respectively.

7-Acetoxy-4-methyl-2-oxo-1H-quinoline (6)

As colorless crystals, yield 63\%, m.p. $144-146^{\circ} \mathrm{C}$. IR $(\mathrm{KBr}) v_{\max }: 3255(\mathrm{NH}), 1771,1679(\mathrm{C}=\mathrm{O})$, 1607, $1587(\mathrm{C}=\mathrm{C}), 1117,1093(\mathrm{C}-\mathrm{O}) \mathrm{cm}^{-1} .{ }^{1} \mathrm{H}-\mathrm{NMR}\left(\mathrm{DMSO}-d_{6}\right) \delta: 2.31\left(\mathrm{~s}, 3 \mathrm{H}, \mathrm{CH}_{3}\right), 2.44(\mathrm{~s}, 3 \mathrm{H}$, $\left.\mathrm{CH}_{3}\right), 6.04(\mathrm{~s}, 1 \mathrm{H}, \mathrm{H}-3$ of quinolinone ring), $7.02(\mathrm{~d}, 1 \mathrm{H}, \mathrm{H}-6$ of quinolinone ring), $7.28(\mathrm{~s}, 1 \mathrm{H}$, $\mathrm{H}-8$ of quinolinone ring), $7.83\left(\mathrm{~d}, 1 \mathrm{H}, \mathrm{H}-6\right.$ of quinolinone ring) ppm. ${ }^{13} \mathrm{C}-\mathrm{NMR}$ (DMSO- $\left.d_{6}\right) \delta$ : $169.31(\mathrm{C}=\mathrm{O}), 160.12,153.97,153.47,153.36,126.90,118.94,117.98,114.19,110.60$ (C2, C7, $\mathrm{C} 3, \mathrm{C} 6, \mathrm{C} 8, \mathrm{C} 5, \mathrm{C} 4, \mathrm{C} 9, \mathrm{C} 10$ of quinolinone ring, respectively), 21.35, $18.65\left(2 \mathrm{x} \mathrm{CH}_{3}\right) \mathrm{ppm}$. MS: $\mathrm{m} / \mathrm{z}(\%)=217\left(\mathrm{M}^{+}, 33.41\right), 175(100)$. Anal. calcd. for $\mathrm{C}_{12} \mathrm{H}_{11} \mathrm{NO}_{3}(217): \mathrm{C}, 66.36 ; \mathrm{H}, 5.07 ; \mathrm{N}$, 6.45. Found: C, 66.13; H, 4.89; N, 6.22.

3-(7-Acetoxy-4-methyl-3,6,8-tribromo-2-oxo-1H-quinolin-1-ylamino)-3-phenyl acrylic acid (7)

As pale-yellow crystals, yield $71 \%$, m.p. $146-148{ }^{\circ} \mathrm{C}$. IR (KBr) $v_{\max }$ : 3420-2450 (br. OH), 3215 $(\mathrm{NH}), 1776,1705,1681(\mathrm{C}=\mathrm{O}), 1612,1578(\mathrm{C}=\mathrm{C}), 1183,1081,1043(\mathrm{C}-\mathrm{O}) \mathrm{cm}^{-1} .{ }^{1} \mathrm{H}-\mathrm{NMR}$ 
(DMSO- $\left.d_{6}\right) \delta: 2.38\left(\mathrm{~s}, 3 \mathrm{H}, \mathrm{COCH}_{3}\right), 2.47,2.63\left(\mathrm{~s}, 3 \mathrm{H}\right.$, two isomer for $\mathrm{CH}_{3}$ for the quinolinone ring), 7.36-8.27 (m, 7H, Ar-H and H-olefinic) ppm. ${ }^{13} \mathrm{C}-\mathrm{NMR}\left(\mathrm{DMSO}-d_{6}\right) \delta: 168.47,168.39(\mathrm{C}=\mathrm{O}$ of acetoxy), 167.42 ( $\mathrm{C}=\mathrm{O}$ of acid), 156.14, 155.93, 155.60, 151.52, 151.41, 151.22, 150.89, 112.24, 106.70, 104.98 (carbon of two isomer of quinolinone ring), 148.98, 148.34, 130.13, $126.35,120.52,120.32,119.56,119.08,112.86,107.21,103.22$ (carbons of aromatic and olefinic), 21.03, $20.70\left(\mathrm{CH}_{3}\right), 20.17,20.09$ (carbons of $\left.\mathrm{COCH}_{3}\right) \mathrm{ppm}$. MS: m/z $(\%)=608\left(\mathrm{M}^{+}\right.$, 1.30). Anal. calcd. for $\mathrm{C}_{21} \mathrm{H}_{11} \mathrm{Br}_{3} \mathrm{~N}_{2} \mathrm{O}_{3}(608)$ : $\mathrm{C}, 41.45 ; \mathrm{H}, 1.81$; N, 4.61. Found: $\mathrm{C}, 41.25 ; \mathrm{H}, 1.63$; $\mathrm{N}, 4.44$.

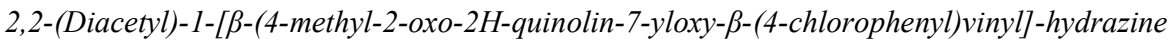

(10)

As pale-yellow crystals, yield $62 \%$, m.p. $178-180{ }^{\circ} \mathrm{C}$. IR (KBr) $v_{\max }: 3222(\mathrm{NH}), 1715-1690$ (br. $\mathrm{C}=\mathrm{O}), 1605,1583(\mathrm{C}=\mathrm{C}), 1172,1070(\mathrm{C}-\mathrm{O}) \mathrm{cm}^{-1} .{ }^{1} \mathrm{H}-\mathrm{NMR}\left(\mathrm{DMSO}-d_{6}\right) \delta: 2.08\left(\mathrm{~s}, 3 \mathrm{H}, \mathrm{COCH}_{3}\right)$, $2.15\left(\mathrm{~s}, 3 \mathrm{H}, \mathrm{COCH}_{3}\right), 2.40\left(\mathrm{~s}, 3 \mathrm{H}, \mathrm{CH}_{3}\right), 4.94(\mathrm{~d}, 1 \mathrm{H}, \mathrm{H}$-olefinic), $5.20(\mathrm{~d}, 1 \mathrm{H}, \mathrm{NH}), 6.25(\mathrm{~s}, 1 \mathrm{H}$, $\mathrm{H}-3$ of quinolinone ring), 7.01-7.67 (m, 7H, Ar-H and quinolinone ring) ppm. ${ }^{13} \mathrm{C}-\mathrm{NMR}$ (DMSO$\left.d_{6}\right) \delta: 167.12(\mathrm{C}=\mathrm{O}$ of acetyl group $), 161.35,160.55,155.05,153.79,126.98,114.28,113.29$, 112.06, 102.57 (C2, C7, C3, C6, C8, C5, C4, C9, C10 of quinolinone ring), 135.28, 135.00, 129.12, 128.66, 99.60 (C-aromatic and olefinic), 67.59 (OCH-), 22.52, 18.62, $11.20\left(3 \times \mathrm{CH}_{3}\right)$ ppm. MS: $\mathrm{m} / \mathrm{z}(\%)=425\left(\mathrm{M}^{+}, 16.30\right)$. Anal. calcd. for $\mathrm{C}_{22} \mathrm{H}_{20} \mathrm{ClN}_{3} \mathrm{O}_{4}(425): \mathrm{C}, 62.12 ; \mathrm{H}, 4.71 ; \mathrm{N}$, 9.88. Found: C, 62.03; H, 4.51; N, 9.66.

\section{Biological assay}

In vitro cancer activity against breast cancer cell line (MCF-7). The cytotoxicity of the synthesized tested compounds was tested using MTT assay. Cells were plated in 96- multiwall plate $\left(10^{4}\right.$ cells/well $)$ for $24 \mathrm{~h}$ before treatment with the compounds to allow attachment of cell to wall of the plate. Different Concentrations of the compound under test were added to the cell monolayer. Six wells were prepared for each individual dose. Monolayer cells were incubated with the compounds for $48 \mathrm{~h}$ at $37{ }^{\circ} \mathrm{C}$ and in atmosphere of $5 \% \mathrm{CO}_{2}$. After $48 \mathrm{~h}$ cells were fixed, washed, and stained with MTT stain. Excess stain was washed with isopropanol and attached stain was recovered with Tris EDTA buffer. Color intensity was measured in an ELISA reader. The relation between surviving fraction and drug conc. is plotted to get the survival curve of each tumor cell line after the specified compound.

Cell cycle analysis. MCF-7 cells $\left(2 \times 10^{5} /\right.$ well) were treated with tested compounds at its $\mathrm{IC}_{50}$ values for $24 \mathrm{~h}$. After treatment, cells were washed twice with ice-cold phosphate buffer saline (PBS), collected by centrifugation, and fixed in ice-cold $70 \%(\mathrm{v} / \mathrm{v})$ ethanol at $4{ }^{\circ} \mathrm{C}$ for $30 \mathrm{~min}$, washed with PBS at $37^{\circ} \mathrm{C}$ for $30 \mathrm{~min}$. Cells were collected by centrifugation at $2000 \mathrm{rpm}$ for 5 min and stained with propidium iodide (PI) buffer, samples were mixed gently and incubated at room temperature in the dark for $20 \mathrm{~min}$. The DNA content was analyzed using BD FACS CALIBER flow cytometer.

Apoptosis determination by Annexin-V-FITC/PI assay. The MCH-7 cells ( $2 \times 10^{5} /$ well) were treated with compound 3 at its $\mathrm{IC}_{50}$ concentration value for $48 \mathrm{~h}$. After treatment, cells were harvested and washed twice $\left(180 \mathrm{~g}, 10 \mathrm{~min}, 4{ }^{\circ} \mathrm{C}\right)$ with PBS. Each cell well was resuspended in $100 \mu \mathrm{L}$ of binding buffer, and $5 \mu \mathrm{L}$ Annexin V-FITC were added. After an incubation time of 10 min at room temperature, additional $400 \mu \mathrm{L}$ of binding buffer were added for a final volume of $500 \mu \mathrm{L}$. Cells were stained with PI immediately before measurement. Cells were the analyzed by using FACSCalibur Flow cytometer (Becton and Dickinson, Heidelberg, Germany). Data thus obtained were analyzed with Cell-Quest software (Becton and Dickinson, Heidelberg, Germany). 


\section{RESULTS AND DISCUSSION}

\section{Chemistry}

The synthetic pathway leading to the 3-(substituted-2-oxoquinolin-1-ylamine)-3-phenyl acrylic acids (3-9) is outlined in (Scheme 1 and 2). The starting 4-hydroxy-4-methylcoumarin (1) was prepared according to published procedure [30]. Treatment of compound $\mathbf{1}$ with hydrazine hydrate in pyridine under reflux led to the formation of 7-hydroxy-4-methyl-2-oxo-1-aminoquinoline (2) according to literature method [31], as a key starting material.

Reaction of 7-hydroxy-4-methyl-2-oxo-1-aminoquinoline (2) with cinnamic acid in the presence of fused sodium acetate in ethanol under reflux gave the corresponding 3-(7-hydroxy-4methyl-2-oxo-2H-quinolin-1-ylamino)-3-phenyl acrylic acid (3).

Structure of compound 3 was confirmed via its transformation into 3-(7-hydroxy-4-methyl3,6,8-tribromo-2-oxoquinolin-1-ylamino)-3-phenyl acrylic acid (4) by bromination of compound $\mathbf{3}$ which contain free hydroxyl and methyl group in positions $\mathbf{3}$ and $\mathbf{7}$, led to the substitution reaction in this compound (3) at position 3,6 and 8 with bromine.

Acetylation of compound 3 with acetic anhydride under reflux was expected to give structure $\mathbf{5}$, but only 7-acetoxy-4-methyl-2-oxo- $1 H$-quinoline (6, known) was yielded, via the elimination of cinnamic acid molecule from compound 3. Compound 6 was prepared by Moustafa et al. via acetylation of 7-hydroxy-4-methyl- $2 H$-quinolinone with acetic anhydride under reflux [32]. While the acetylation of compound $\mathbf{4}$ with acetic anhydride under boiling led to the expected structure of 3-(7-acetoxy-4-methyl-3,6,8-tribromo-2-oxo-2H-quinolin-1-ylamino)-3-phenyl acrylic acid (7) without elimination of cinnamic acid molecule from the compound 4. Alkylation of 3-(7-hydroxy-4-methyl-2-oxo-2H-quinolin-1-ylamino)-3-phenyl acrylic acid (3) with $p$ chlorophenacyl bromide in ethanol in the presence of anhydrous potassium carbonate under reflux gave the corresponding 3-[7-(p-chlorophenacyloxy)-4-methyl-2-oxo- $2 H$-quinoline-1-ylamino]3-phenyl acrylic acid (8).

Treatment of compound $\mathbf{8}$ with hydrazine hydrate in ethanol under reflux led to the formation of hydrazine derivative (9). Acetylation of hydrazine derivative with acetic anhydride under reflux led to the formation of 2,2-(diacetyl)-1-[ $\beta$-(4-methyl-2-oxo- $2 H$-quinolin-7-yloxy- $\beta$-(4chlorophenyl)vinyl]-hydrazine (10).

NMR spectra investigation of some synthesized 2-quinolinone derivatives (3-10)

Chemical structure of 2-quinolinone and the numbering of 2-quinolinone ring as shown in Formula IV.

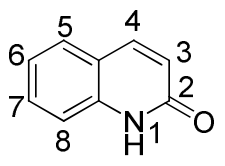

Formula IV. Structure and numbering of 2-quinolinone ring.

From the data of NMR spectrum for the compound $\mathbf{3}$ showed that the presented one isomer only. ${ }^{1} \mathrm{H}-\mathrm{NMR}$ spectrum of compound 3 gave clear cut evidence three singlet signals at 10.55, 6.13 and $2.36 \mathrm{ppm}$ due to the protons of hydroxyl group $(\mathrm{OH}), \mathrm{H}-3$ and methyl group $\left(\mathrm{CH}_{3}\right)$ at position $-7,-3$ and -4 in the quinolinone ring. Protons of the aromatic, olefinic and region at $6.51-$ $7.70 \mathrm{ppm}$ and exhibited the expected integral values.

The ${ }^{13} \mathrm{C}-\mathrm{NMR}$ spectrum of compound 3 showed that the presented among total 17 carbon signals. The carbon signals due to the 2-quinolinone ring at $161.10(\mathrm{C}-2), 160.79$ (C-7), 155.29 (C-3), 154.08 (C-6), 127.13 (C-8), 113.33 (C-5), 112.49 (C-4), 110.71 (C-9), 102.63 (C-10) and 


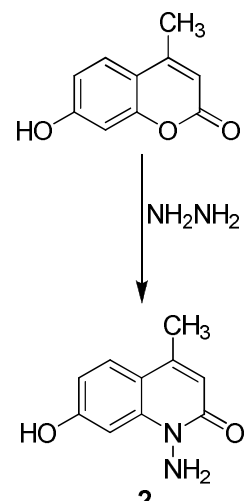

2
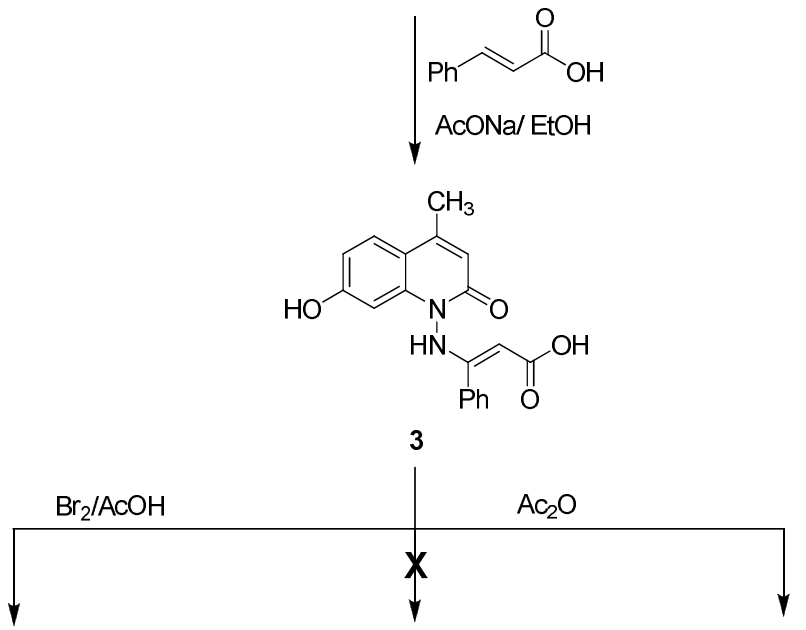

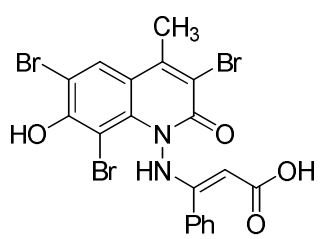

4

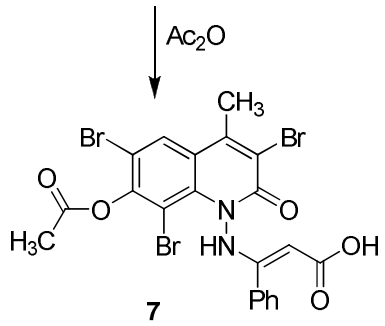

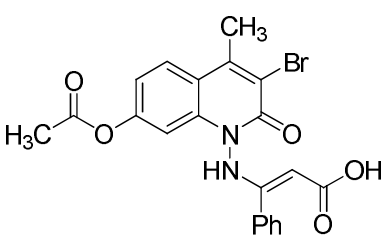

5

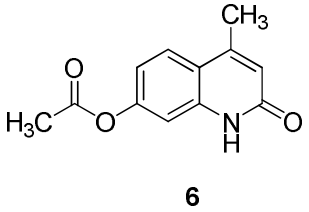

6

Scheme 1

Bull. Chem. Soc. Ethiop. 2021, 35(3) 


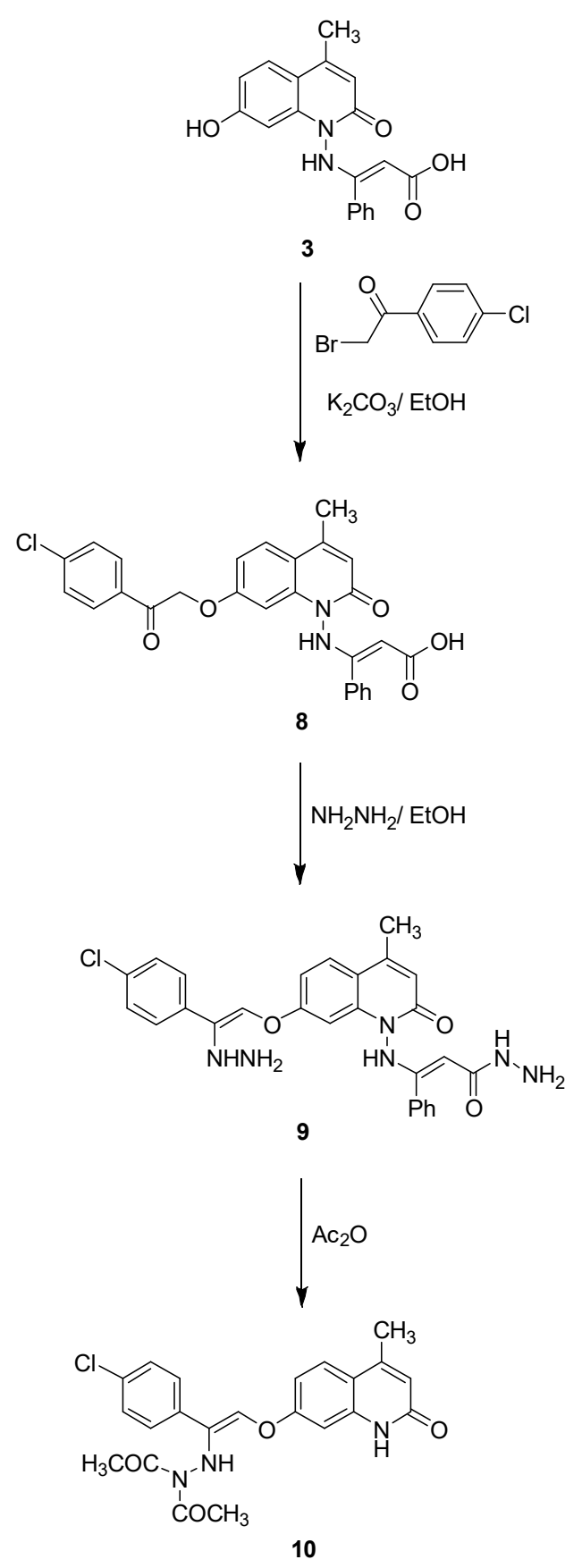

Scheme 2

Bull. Chem. Soc. Ethiop. 2021, 35(3) 
$18.59 \mathrm{ppm}\left(\mathrm{CH}_{3}\right.$ at position 4$)$. Also, ${ }^{13} \mathrm{C}$-NMR spectrum of compound $\mathbf{3}$ revealed a characteristic carbon signal at $168.05(\mathrm{C}=\mathrm{O}$ of carboxylic acid), $144.43(\mathrm{~N}-\mathrm{C}=), 134.66,130.71,129.38,128.68$, $119.64 \mathrm{ppm}$ due to the carbons of cinnamic acid, among total 9 carbon signals. From study, the NMR spectrum of halogenated compound $\mathbf{4}$ showed that the presented two isomers (cis and trans isomers) as shown in Formula $\mathbf{V}$.
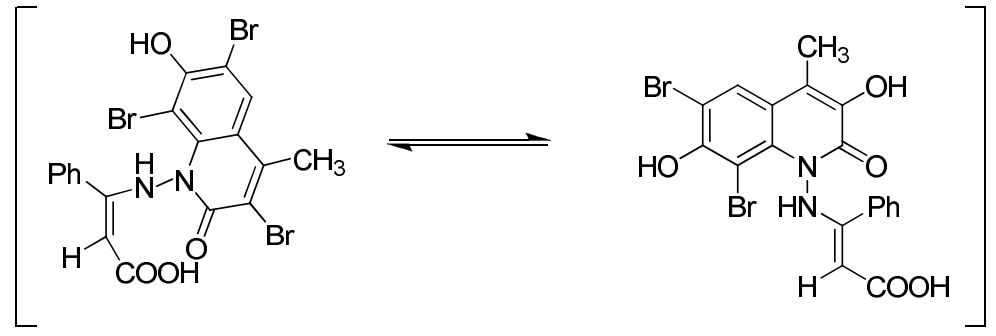

Formula V. cis and trans isomers of compound 4.

${ }^{1} \mathrm{H}-\mathrm{NMR}$ spectrum of compound $\mathbf{4}$ showed that the presented two characteristic signals at 11.57 and 11.49 ppm refer to the protons of hydroxyl group at C-7 in the cis and trans isomers of quinolinone ring, and at 2.57, 2.55 ppm attributed to the protons of methyl group at C-4 in cis and trans isomers of quinolinone ring. In addition, ${ }^{1} \mathrm{H}-\mathrm{NMR}$ spectrum of compound 4 exhibited two doublet signals at 5.32 and $5.54 \mathrm{ppm}$ assigned to one proton of olefinic in cis and trans isomers in the cinnamic acid. Finally, protons of the aromatic ring and hydroxyl group of carboxylic acid $(\mathrm{OH})$ were observed in the expected chemical shift in the region at 6.89-8.07 and 13.84 ppm, respectively.

The ${ }^{13} \mathrm{C}-\mathrm{NMR}$ spectrum of compound 4 displayed ten carbon signals for the cis isomer of quinolinone ring at 158.77 (C-2), 156.68 (C-7), 156.21 (C-3), 152.40 (C-6), 151.45 (C-8), 114.78 (C-5), $110.19(\mathrm{C}-4), 108.64(\mathrm{C}-9), 99.82$ (C-10), $19.87\left(\mathrm{CH}_{3}\right.$ in the position 4 of quinolinone ring) and assigned to ten carbon signals for the trans isomer of quinolinone ring at 157.89 (C-2), 156.55 (C-7), 151.72 (C-6), 150.47 (C-8), 113.40 (C-5), 109.08 (C-4), 108.22 (C-9), 97.24 (C-10), 19.87 $\left(\mathrm{CH}_{3}\right.$ in the position 4 of quinolinone ring). The ${ }^{13} \mathrm{C}-\mathrm{NMR}$ spectrum of compound 4 confirmed the cis and trans isomers, which appeared the two signals of olefinic carbon at 52.36 and 47.65 ppm. Also, the ${ }^{13} \mathrm{C}-\mathrm{NMR}$ spectrum of compound $\mathbf{4}$ displayed new signal at $169.56 \mathrm{ppm}$ due to the carbonyl function of carboxylic acid.

From study, the ${ }^{1} \mathrm{H}-\mathrm{NMR}$ spectrum of compound $\mathbf{8}$ showed the structure of these compounds in keto-enol tautomers as shown in Formula VI.

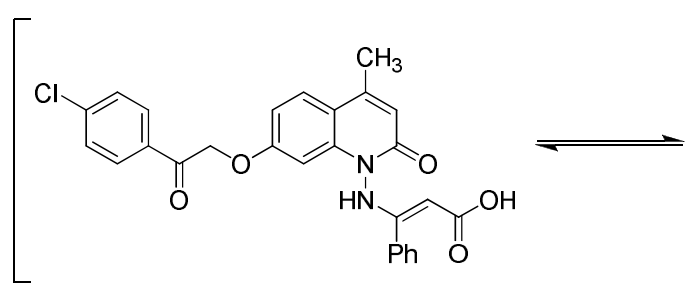

Keto-form<smiles>Cc1cc(=O)n(NC(=CC(=O)O)c2ccccc2)c2cc(OC=C(O)c3ccc(Cl)cc3)ccc12</smiles>

Enol-form

Formula VI. Keto-enol tautomers of compound 8. 
${ }^{1} \mathrm{H}-\mathrm{NMR}$ spectrum of compound $\mathbf{8}$ showed that the presented two characteristic singlet signals at $10.55 \mathrm{ppm}$ refer to the proton of hydroxyl group $(\mathrm{OH})$ for the enol form, and $5.74 \mathrm{ppm}$ attributed to the protons of methylene group $\left(-\mathrm{OCH}_{2}\right)$ for the keto form. This occurred when both structures are in unequilibrium state. In addition, ${ }^{1} \mathrm{H}-\mathrm{NMR}$ spectrum of compound $\mathbf{8}$ exhibited three singlet signals at $6.13,3.72$ and $2.36 \mathrm{ppm}$ assigned to the protons of $\mathrm{H}-3$ of quinolinone ring, $\mathrm{CH}$ olefinic (enol form) and methyl group $\left(\mathrm{CH}_{3}\right)$, respectively.

Finally, the ${ }^{1} \mathrm{H}-\mathrm{NMR}$ spectrum of compound $\mathbf{8}$ displayed multiplet signals in the region at 6.22-8.06 ppm due to the aromatic, olefinic and amino $(\mathrm{NH})$ protons.

The ${ }^{13} \mathrm{C}-\mathrm{NMR}$ spectrum of compound $\mathbf{8}$ showed the presence of two carbon signals at 193.36 (carbonyl of ketone) and $71.01 \mathrm{ppm}$ (methylene group) refer to the methylene carbonyl $\left(-\mathrm{CH}_{2}-\right.$ $\mathrm{C}=\mathrm{O}$ ) and supported that the presented keto form.

The ${ }^{13} \mathrm{C}$-NMR spectrum of compound $\mathbf{8}$ displayed new signal at 51.96 due to the carbon olefinic $(-\mathrm{OCH}=\mathrm{C}-\mathrm{OH})$, these signals further supported that the presented enol form. In addition, the spectrum of compound $\mathbf{8}$ showed the carbon signals of two isomers at 161.61, 161.46, (C-2), 160.78, 160.59 (C-7), 155.29, 155.09 (C-3), 154.05, 153.87 (C-6), 127.58, 127.11 (C-8), 113.91, 113.32 (C-5), 113.04, 112.48 (C-4), 111.77, 110.71 (C-9), 102.63, 102.06 (C-10) and 18.61, 18.58 $\left(2 \times \mathrm{CH}_{3}\right) \mathrm{ppm}$. The ${ }^{13} \mathrm{C}$-NMR spectrum of compound $\mathbf{8}$ showed two signals at 168.06 and 167.15 assigned to carbonyl of the carboxylic group $(\mathrm{COOH})$. Finally, ${ }^{13} \mathrm{C}-\mathrm{NMR}$ spectrum of compound 8 revealed a characteristic carbon signal in the region at $145.03-118.25 \mathrm{ppm}$ due to the aromatic and olefinic carbons.

The ${ }^{1} \mathrm{H}-\mathrm{NMR}$ spectrum of compound $\mathbf{1 0}$ showed a sharp three signals at 2.081, 2.15 and 2.40 ppm due to the protons of three methyl groups and sharp singlet signal at $6.25 \mathrm{ppm}$ due to the $\mathrm{H}$ 3 of quinolinone ring.

The protons demonstrated two signals at 5.20 and 4.94 as doublet due to the NH and CHolefinic. Protons of the aromatic ring were observed within the expected chemical shift in the region at 7.01-7.67 ppm.

The ${ }^{13} \mathrm{C}$-NMR spectrum of compound 10 showed signal at 167.12, 22.52, 18.62 and 11.20 ppm assigned to carbonyl $(\mathrm{C}=\mathrm{O})$ and three methyl groups. $\mathrm{CH}$-olefinic displayed a signal at 161.35 (C-2), 160.55 (C-7), 155.05 (C-3), 153.79 (C-6), 126.98 (C-8), 114.28 (C-5), 113.29 (C4), 112.06 (C-9), 102.57 (C-10) ppm. In addition, the spectrum of these compound showed signals at $135.28,135.00,129.12,128.66,99.60 \mathrm{ppm}$ refer to the aromatic and olefinic carbons for the $p$ chlorophenyl group.

\section{Biological investigation}

Anti-tumor activity against breast carcinoma (MCF-7) cells. Hybrid 2-quinolinone 3, 4, 7, 9 and 10 were tested for their effect on the viability of breast carcinoma (MCF-7) cell line using MTT assay. The cytotoxicity was assessed using Dox as positive control. Treatment of MCF-7 cell line with different concentration of 2-quinolinonederivatives revealed that some of the tested compounds showed promising cytotoxic activity against MCF-7 cells as concluded from their $\mathrm{IC}_{50}$ values as shown in Table 2. Structurally, 3-(7-hydroxy-4-methyl-2-oxo-2H-quinolin-1ylamino)-3-phenyl acrylic acid (3) showed the highest cytotoxic activity against MCF-7 cells. In conclusion, 3 was the most potent antitumor compound over MCF-7 cell line which had $\mathrm{IC}_{50}$ value of $3.02 \mu \mathrm{M}$ which was comparable of $2.29 \mu \mathrm{M}$ of Dox.

Cell cycle analysis of compound 3. To study the mechanism of anticancer activity of compound 3, cell cycle analysis was carried out using DNA flow cytometry analysis in MCF-7 cells. MCF7 cells were incubated with $\mathrm{IC}_{50}$ concentration of compound 3 for $24 \mathrm{~h}$ and then subjected to DNA flow cytometry analysis. As shown in Figure 1, exposure of MCF-7 cells to compound 3 resulted in interference of the normal cell distribution in the cell cycle profile of MCF-7 cells. Compound 3 could enhance the G2/M phase by $12.02 \%$ compared with the untreated control. This effect was 
accompanied by increase in cell percentage in pre- $\mathrm{G}_{1}$ phase of the cell cycle. These results suggested that compound 3 induce cancer cell death via G2/M phase arrest with apoptosis inducing activity marked by the presence pre- $\mathrm{G}_{1}$ peak in the cell cycle distribution profile of MCF7 cells.

Table 2. Calculated $\mathrm{IC}_{50}(\mu \mathrm{M})$ for compounds $3,4,7,9$ and 10 against breast carcinoma (MCF-7) cells.

\begin{tabular}{|c|c|}
\hline Comp No. & $\mathrm{IC}_{50}(\mu \mathrm{M}) / \mathrm{MCF}-7$ \\
\hline $\mathbf{3}$ & $3.02 \pm 0.17$ \\
\hline $\mathbf{4}$ & $3.83 \pm 0.21$ \\
\hline $\mathbf{7}$ & $>100$ \\
\hline $\mathbf{9}$ & $36.32 \pm 0.31$ \\
\hline $\mathbf{1 0}$ & $63.39 \pm 0.28$ \\
\hline Dox & $2.29 \pm 0.09$ \\
\hline
\end{tabular}
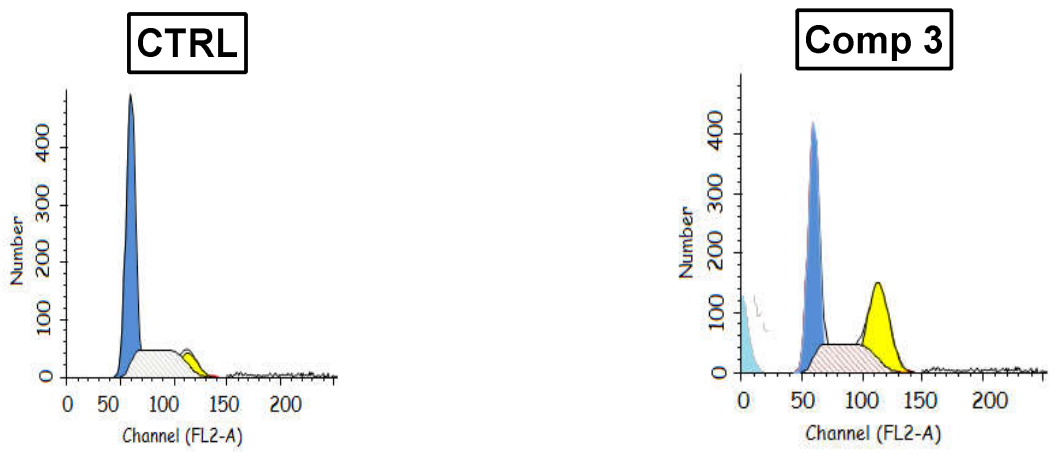

Figure 1. Effect of compound 3 on the cell cycle profile of MCF-7.
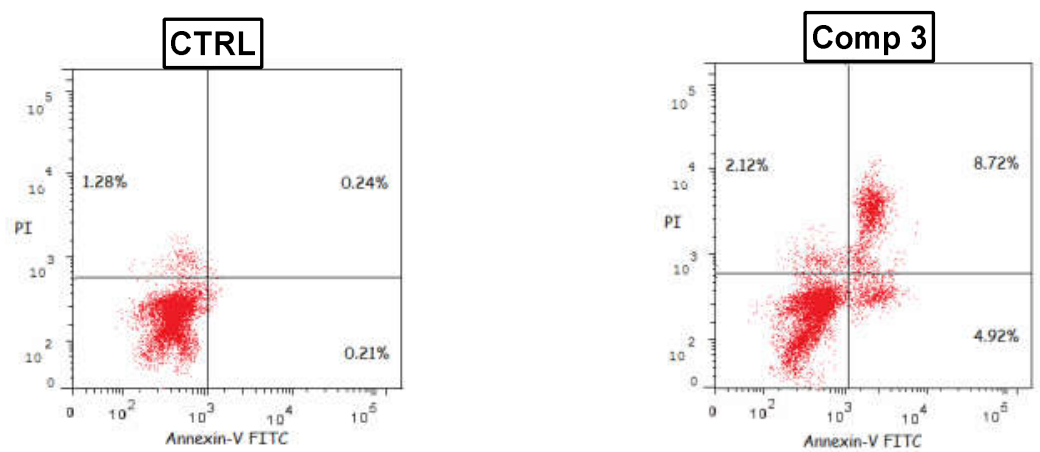

Figure 2. Annexin-V FITC analysis of compound 3.

Annexin V-FITC/PI and detection of apoptosis of compound 3. To examine the anticancer activity of the prepared compound, the effect of the synthesized compounds on the viability of MCF-7 cell line was measured using colorimetric MTT assay after $48 \mathrm{~h}$ of incubation. To determine the 
apoptosis inducing activity of compound 3. A biparametric cytofluorimetric analysis was performed for compound 3 at its $\mathrm{IC}_{50}$ concentration, using AnnexinV/PI. As shown in (Figure 2), the selected compound showed a sharp decrease in the cell survival percentage in comparison with control. Also, compound 3 increase the percentage of early apoptotic cells by 23.42-fold more than control. Moreover, compound 3 increase the percentage of late apoptotic cells by $36.33-$

fold more than control. These results suggested that, compound $\mathbf{3}$ increase the apoptosis of MCF7 cells.

\section{CONCLUSION}

In conclusion, we have synthesized a new class of hybrid 2-quinolinone and hybrid halogenated 2 -quinolinone derivatives containing cinnamic acid by using $\beta$-hydroxy-4-methyl-1-aminoquinolin-2-one (2) and cinnamic acid as starting materials. The structure of the prepared compounds was proved using spectral and elemental analysis data. All the prepared 2-quinolinone and hybrid halogenated 2-quinolinone derivatives were tested for their in vitro cytotoxicity against MCF-7 cell line and compound 3 was the most active one. DNA flow cytometric analysis of compounds 3 showed cell cycle arrest at $\mathrm{G}_{2} / \mathrm{M}$ phase with concomitant increase of cells in apoptotic phase. Dual annexin-V/propidium iodide staining assay of compound 3 revealed that, the selected molecule increases the apoptosis of MCF-7 cells more than control.

\section{REFERENCES}

1. Via, L.D.; Gia, O.; Gasparotto, V.; Ferlin, M.G. Discovery of a new anilino-3H-pyrrolo[3,2f]quinoline derivative as potential anti-cancer agent. Eur. J. Med. Chem. 2008, 43, 429-434.

2. Hawtin, R.E.; Stockett, D.E.; Byl, J.A.W.; McDowell, R.S.; Tan, N.; Arkin, M.R.; Conroy, A.; Yang, W.; Osheroff, N.; Fox, J.A. Voreloxin is an anticancer quinolone derivative that intercalates DNA and poisons topoisomerase II. PLoS One 2010, 5, e10186.

3. Daniel, K.G.; Chen, D.; Orlu, S.; Cui, Q.C.; Miller, F.R.; Dou, Q.P. Clioquinol and pyrrolidine dithiocarbamate complex with copper to form proteasome inhibitors and apoptosis inducers in human breast cancer cells. Breast Cancer Res. 2005, 7, R897.

4. Ding, W.-Q.; Liu, B.; Vaught, J.L.; Yamauchi, H.; Lind, S.E. Anticancer activity of the antibiotic clioquinol. Cancer Res. 2005, 65, 3389.

5. Du, T.; Filiz, G.; Caragounis, A.; Crouch, P.J.; White, A.R. Clioquinol promotes cancer cell toxicity through tumor necrosis factor $\alpha$ release from macrophages. J. Pharmacol. Exp. Ther. 2008, 324, 360-367.

6. Mao, X.; Li, X.; Sprangers, R.; Wang, X.; Venugopal, A.; Wood, T.; Zhang, Y.; Kuntz, D.A.; Coe, E.; Trudel, S.; Rose, D.; Batey, R.A.; Kay, L.E.; Schimmer; A.D. Clioquinol inhibits the proteasome and displays preclinical activity in leukemia and myeloma. Leukemia 2009, 23, 585-590.

7. Ganguly, A.; Banerjee, K.; Chakraborty, P.; Das, S.; Sarkar, A.; Hazra, A.; Banerjee, M.; Maity, A.; Chatterjee, M.; Mondal, N.B.; Choudhuri, S.K. Overcoming multidrug resistance (MDR) in cancer in vitro and in vivo by a quinoline derivative. Biomed. Pharmacother. 2011, 65, 387-394.

8. Tseng, C.-H.; Tzeng, C.-C.; Chung, K.-Y.; Kao, C.-L.; Hsu, C.-Y.; Cheng, C.-M.; Huang, K.S.; Chen, Y.-L. Synthesis and antiproliferative evaluation of 6-aryl-11-iminoindeno[1,2c]quinoline derivatives. Bioorg. Med. Chem. 2011, 19, 7653-7663.

9. Sharma, S.; Panjamurthy, K.; Choudhary, B.; Srivastava, M.; Shahabuddin, M.S.; Giri, R.; Advirao, G.M.; Raghavan, S.C. A novel DNA intercalator, 8-methoxy pyrimido[ $\left.4^{\prime}, 5^{\prime}: 4,5\right]$ thieno $(2,3-b)$ quinoline- $4(3 \mathrm{H})$-one induces apoptosis in cancer cells, inhibits the tumor progression and enhances lifespan in mice with tumor. Mol. Carcinog. 2013, 52, 413-425. 
10. Collins, M.K.L.; Lopez, R.A. The control of apoptosis in mammalian cells. Trends Biochem. Sci. 1993, 18, 307-309.

11. Franceschi, C. Cell proliferation, cell death and aging. Aging Clinic. Experim. Res. 1989, 1, 3-15.

12. Wyllie, A.H. Apoptosis and the regulation of cell numbers in normal and neoplastic tissues: An overview. Cancer Metastasis Rev. 1992, 11, 95-103.

13. Kemnitzer, W.; Kuemmerle, J.; Jiang, S.; Zhang, H.-Z.; Sirisoma, N.; Kasibhatla, S.; CroganGrundy, C.; Tseng, B.; Drewe, J.; Cai, S.X. Discovery of 1-benzoyl-3-cyanopyrrolo[1,2a]quinolines as a new series of apoptosis inducers using a cell- and caspase-based highthroughput screening assay. Part 1: Structure-activity relationships of the 1- and 3-positions. Bioorg. Med. Chem. Lett. 2008, 18, 6259-6264.

14. Jagadale, S.; Salunkhe, J. To evaluate the effectiveness of kangaroo mother care on low birth weight babies. Int J Sci Res. 2017, 3, 2319.

15. Al-Bayati, R.I.; Ahamed, M.R.; Ahmed, L.S. Synthesis and biological activity investigation of some quinoline-2-one derivatives. Am. J. Org. Chem. 2015, 5, 125-135.

16. Patil, S.; Kuman, M.M.; Palvai, S.; Sengupta, P.; Basu, S. Impairing powerhouse in colon cancer cells by hydrazide-hydrazone-based small molecule. ACS Omega 2018, 3, 1470-1481.

17. Verma, G.; Marella, A.; Shaquiquzzaman, M.; Akhtar, M.; Ali, M.R.; Alam, M.M. A review exploring biological activities of hydrazones. J. Pharm. Bioallied Sci. 2014, 6, 69.

18. Kumar, S.; Bawa, S.; Gupta, H. Biological activities of quinoline derivatives. Mini Rev. Med. Chem. 2009, 9, 1648-1654.

19. Chen, Y.-F.; Lin, Y.-C.; Morris-Natschke, S.L.; Wei, C.-F.; Shen, T.-C.; Lin, H.-Y.; Hsu, M.H.; Chou, L.-C.; Zhao, Y.; Kuo, S.-C.; Lee, K.-H.; Huang, L.-J. Synthesis and SAR studies of novel 6,7,8-substituted 4-substituted benzyloxyquinolin-2(1H)-one derivatives for anticancer activity. British J. Pharmacol. 2015, 172, 1195-1221.

20. Ghorab, M.M.; Alsaid, M.S. Anti-breast cancer activity of some novel quinoline derivatives. Acta Pharma 2015, 65, 271-283.

21. Ferretti, M.D.; Neto, A.T.; Morel, A.F.; Kaufman, T.S.; Larghi, E.L. Synthesis of symmetrically substituted 3,3-dibenzyl-4-hydroxy-3,4-dihydro-1H-quinolin-2-ones, as novel quinoline derivatives with antibacterial activity. Eur. J. Med. Chem. 2014, 81, 253-266.

22. Proisl, K.; Kafka, S.; Kosmrlj, J. Chemistry and applications of 4-hydroxyquinolin-2-one and quinoline-2, 4-dionebased compounds. Curr. Org. Chem. 2017, 21, 1949-1975.

23. Nadaraj, V.; Selvi, S.T.; Sasi, R. Microwave-assisted synthesis of quinoline alkaloids: 4methoxy-1-methyl-2-quinolinone and its analogs. Arkivoc 2006, 10, 82-89.

24. Peet, N.P. Drug resistance: A growing problem. Drug Discovery Today 2010, 15, 583-586.

25. Eicher, T.; Hauptmann, S. The Chemistry of Heterocycles, 2nd ed., Wiley-VCH: Weinheim, Germany; 2003; pp. 316-336.

26. Feng, Y.; Lau, E.; Scortegagna, M.; Ruller, C.; De, S.K.; Barile, E.; Krajewski, S.; Aza-Blanc, P.; Williams, R.; Pinkerton, A.B. Inhibition of melanoma development in the Nras(Q61K): Ink4a(-/-) mouse model by the small molecule BI-69A11. Pigm. Cell Melanoma Res. 2013, 26, 136-142.

27. Shi, A.; Nguyen, T.A.; Battina, S.K.; Rana, S.; Takemoto, D.J.; Chiang, P.K.; Hua, D.H. Synthesis and anti-breast cancer activities of substituted quinolones. Bioorg. Med. Chem. Lett. 2008, 18, 3364-3368.

28. Wall, M.E.; Wani, M.C.; Cook, C.E.; Palmer, K.H.; McPhail, A.T.; Sim, G.A. Plant antitumor agents. I. The isolation and structure of camptothecin, a novel alkaloidal leukemia and tumor inhibitor from Camptotheca acuminata. J. Am. Chem. Soc. 1966, 88, 3888-3890.

29. Sawada, S.; Okajima, S.; Aiyama, R.; Nokata, K.I.; Furuta, T.; Yokokura, T.; Sugino, E.; Yamaguchi, K.; Miyasaka, T. Synthesis and antitumor activity of 20(S)-camptothecin derivatives: Carbamate-linked, water-soluble derivaties of 7-ethyl-10-hydroxycamptothecin. Chem. Pharm. Bull. 1991, 39, 1446-1454. 
30. Soliman, A.Y.; El-Assy, N.B.; El-Shahed, F.; El-Kady, M.; ElDeen, I.M. Synthesis and reactions of a 2(4-methyl-2-oxo-2H-1-benzop yran-7-yloxomethyl)-4H-3,1-benzoxazin-4one. Ind. J. Chem. Sect. B 1990, 29B, 326-330.

31. Alka, P.; Sanjay, K.V. Synthesis, characterisation and antimicrobial activity of Schiff base of 7hydroxy-3-methyl-2-quinolone. Int. J. Theor. Appl. Sci. 2018, 10, 40-45.

32. Moustafa, A.M.Y.; Bakare, S.B.; Synthesis of some hybrid 7-hydroxy quinolinone derivatives as anti breast cancer drugs. Res. Chem. Intermed. 2019, 45, 3895-3912. 